\title{
Difference in the Faecal Elastase-1 Concentration between Resectable and Unresectable Pancreatic Cancer
}

\author{
Abdul Rahman $M^{*}$, Marcelus Simadibrata**, Irsan Hasan ${ }^{* * *}$, Suhendro***, \\ E Mudjadid***** \\ *Department of Internal Medicine, Faculty of Medicine, Universitas Indonesia/ \\ Dr. Cipto Mangunkusumo General National Hospital, Jakarta \\ ** Division of Gastroenterology, Department of Internal Medicine, Faculty of Medicine \\ Universitas Indonesia/Dr. Cipto Mangunkusumo General National Hospital, Jakarta \\ *** Division of Hepatobiliary, Department of Internal Medicine, Faculty of Medicine \\ Universitas Indonesia/Dr. Cipto Mangunkusumo General National Hospital, Jakarta \\ **** Division of Infection and Tropical Disease, Department of Internal Medicine \\ Faculty of Medicine, Universitas Indonesia/Dr. Cipto Mangunkusumo General National Hospital, Jakarta \\ ***** Division of Psychosomatic, Department of Internal Medicine, Faculty of Medicine \\ Universitas Indonesia/Dr. Cipto Mangunkusumo General National Hospital, Jakarta
}

\begin{abstract}
Corresponding author:
Marcellus Simadibrata. Division of Gastroenterology, Department of Internal Medicine, Dr. Cipto Mangunkusumo General National Hospital. Jl. Diponegoro No.71 Jakarta Indonesia. Phone: +62-21-3153957; facsimile: +6221-3142454.E-mail:prof.marcellus.s@gmail.com.
\end{abstract}

\begin{abstract}
Background: In the pancreatic cancer can occur pancreatic exocrine insufficiency (PEI) that can be detected by measurement of fecal elastase-1 level. The aim of this study was to identify the proportion and the degree of PEI, proportion of steatorrhea in pancreatic cancer, the concentration difference of faecal elastase-1 between resectable and unresectable pancreatic cancer and mean concentration difference of faecal elastase-1 based on the stage of pancreatic cancer.

Method: This was a cross-sectional study to determine the concentration difference offaecal elastase-1 between resectable and unresectable pancreatic cancer. This research was conducted at Cipto Mangunkusumo hospital, several network hospitals of Cipto Mangunkusumo hospital, and Wahidin Sudirohusodo Makasar hospital from November 2014 until May 2015. The statistical test used to assess differences in the levels of faecal elastase-1 between resectable and unresectable pancreatic cancer was Mann Whitney and Kruskal Wallis test was performed to assess the differences between the mean levels of faecal elastase 1 based on staging pancreatic cancer.

Results: A total of 48 subjects with pancreatic cancer participated in this study, with resectable category was $19(39.6 \%)$ subjects, and $29(60.4 \%)$ subjects were unresectable. The proportion of patients with pancreatic cancer who experienced PEI was 75\% (95\% CI: 0.63 - 0.87) and the proportion of patients with pancreatic cancer who showed steatorrhea symptoms was $68.8 \%$ (95\% CI: 0.557 - 0.819). There was no significant difference of faecal elastase-1 levels $(P=0.738)$ between the resectable and unresectable whereas the resectable group median value was 38.0 (15-500) $\mu \mathrm{g} / \mathrm{g}$ and in unresectable group was 35.0 (15-500) $\mu \mathrm{g} / \mathrm{g}$. There was no significant difference $(p=0.767)$ in faecal elastase-1 levels based on the stage of pancreatic cancer with median (range) in stage IB $36(15-100) \mathrm{pg} / \mathrm{g}$, stage IIA $62(15-500) \mathrm{pg} / \mathrm{g}$, stage III $15(15-500) \mu \mathrm{g} / \mathrm{g}$, and stage IV $36(15-500) \mu \mathrm{g} / \mathrm{g}$.
\end{abstract}


Conclusion: This study found a high proportion of PEI and steatorrhea in pancreatic cancer. There was no significant difference in faecal elastase-1 levels between the resectable and unresectable pancreatic cancer. There was no significant difference between mean levels of faecal elastase-1 based on the stage of pancreatic cancer.

Keywords: pancreatic exocrine insufficiency (PEI), faecal elastase-1, pancreatic cancer

\section{ABTRAK}

Latar belakang: Pada kanker pankreas dapat terjadi pancreatic exocrine insufficiency (PEI), yang dapat dideteksi dengan pemeriksaan kadar faecal elastase-1. Tujuan penelitian yaitu mengetahui proporsi dan derajat PEI, proporsi steatorrhea pada kanker pankreas, perbedaan kadar faecal elastase-1 antara kanker pankreas yang resectable dan unresectable dan perbedaan rerata kadar faecal elastase-1 berdasarkan stadium kanker pankreas.

Metode: Penelitian ini adalah studi potong lintang untuk menentukan perbedaan kadar faecal elastase-1 antara kanker pankreas yang resectable dan unresectable. Penelitian ini dilakukan di Rumah Sakit Cipto Mangunkusumo, beberapa rumah sakit jejaring RSCM, dan RS Wahidin Sudirohusodo Makasar dari bulan November 2014 sampai dengan Mei 2015. Uji statistik yang digunakan untuk menilai perbedaan kadar faecal elastase-1 antara kanker pankreas yang resectable dan unresectable adalah Mann Whitney dan untuk menilai perbedaan rerata kadar faecal elastase 1 berdasarkan stadium kanker pankreas adalah Kruskal Wallis.

Hasil: Sebanyak 48 subyek kanker pankreas diikutkan dalam penelitian, dengan kategori resectable sebanyak 19 (39,6\%) subyek, dan 29 (60,4\%) subyek yang unresectable. Proporsi pasien kanker pankreas yang mengalami PEI sebanyak 75\% (95\% CI: 0,63-0,87) dan proporsi pasien kanker pankreas yang memberikan gejala steatorrhea sebanyak 68,8\% (95\% CI: 0,557-0,819). Tidak ada perbedaan kadar faecal elastase 1 yang bermakna $(p=0,738)$ antara kelompok resectable dan unresectable dengan nilai median pada kelompok resectable adalah 38,0(15-500) $\mu \mathrm{g} / \mathrm{g}$ dan pada kelompok unresectable adalah 35,0 (15-500) $\mu \mathrm{g} / \mathrm{g}$. Tidak ada perbedaan bermakna $(p=0,767)$ kadar faecal elastase-1 berdasarkan stadium kanker pankreas dengan nilai median(rentang) pada stadium IB 36(15-100) $\mu \mathrm{g} / \mathrm{g}$, stadium IIA 62 (15-500) $\mu \mathrm{g} / \mathrm{g}$, stadium III 15 (15-500) $\mu \mathrm{g} / \mathrm{g}$, dan stadium IV $36(15-500) \mu \mathrm{g} / \mathrm{g}$.

Simpulan: Pada penelitian ini didapatkan proporsi PEI dan steatorrhea yang tinggi pada kanker pankreas. Tidak ditemukan perbedaan bermakna kadar faecal elastase-1 antara kanker pankreas yang resectable dan unresectable. Tidak terdapat perbedaan rerata kadar faecal elastase 1 berdasarkan stadium kanker pankreas.

Kata kunci: pancreatic exocrine insufficiency (PEI), faecal elastase-1, kanker pancreas

\section{INTRODUCTION}

Pancreatic cancer accounts for 3\% from all types of cancer in the United States and contributes to $7 \%$ mortality caused by cancer. ${ }^{1}$ In the world, it is documented that 220,000 deaths every year are caused by pancreatic cancer which is ranked 6th as the cause of cancer mortality. ${ }^{2}$ In Indonesia, data from Cipto Mangunkusumo Hospital in 2004-2008 from 139 patients who underwent endoscopic retrograde cholangio- pancreaticography (ERCP), it was found that the most common cause of malignancy was papilla tumour $(43,8 \%)$, pancreatic head carcinoma (31.3\%) followed by cholangiocarcinoma $(18,8 \%){ }^{3}$ A study in similar location by Kurniawan J, conducted in 2010 until 2014, from 180 patients with obstructive icterus, most of them was caused by pancreatic cancer, particularly 101 patients $(55,8 \%){ }^{4}$ This malignancy may arise from exocrine or endocrine cells. Although this process may affect the endocrine or exocrine functions, the disturbance of endocrine function is usually not significant, whereas the incidence of exocrine cell cancer is more frequent, and $95 \%$ were adenocarcinoma. ${ }^{1}$ In pancreatic cancer, complications may occur due to the obstruction of pancreatic duct, particularly when the tumour location was on the head of the pancreas, thus inhibiting the transfer of bicarbonate and pancreatic enzymes, such as lipase, amylase, protease dan elastase 1 into the duodenum which are needed in the digestion process. This condition is even aggravated by the incidence of fibrosis and gland atrophy as a result of chronic inflammation on the parenchyma due to pancreatic cancer which also causes decreased pancreatic enzyme production. ${ }^{5,6}$ The disturbance of this physiological 
processes may cause inadequate enzyme activity to maintain normal digestion processes, also known as the insufficiency of pancreatic exocrine function or pancreatic exocrine insufficiency (PEI).$^{7-9}$

In patients with pancreatic cancer, we may find symptoms such as changes in appetite, steatorrhea and clay-coloured stool, abdominal pain, jaundice, bloating, burping, decreased body weight, dark -coloured urine, constipation, diarrhoea, itchy, fatigue, sleep disturbance, and chest pain. ${ }^{1,10,11}$ Some of these symptoms such as steatorrhea, abdominal pain, diarrhoea, bloating, and decreased body weight might be caused by the tumour itself or as symptoms of PEI which was a complication of pancreatic cancer progression. The incidence of PEI in pancreatic cancer was documented in $68-92 \%$ patients. ${ }^{5-7,9,12-15}$ Pancreatic exocrine function was relatively difficult to evaluate because the organ location and its secretion are difficult to reach. There were several options to diagnose the insufficiency of pancreatic exocrine function including the use of direct or invasive method and indirect or non-invasive method. ${ }^{7}$ Invasive method is the gold standard with highest sensitivity and specificity to evaluate pancreatic exocrine function. This method is rarely applied because it is difficult to perform, limited cost and human resources, and the invasive characteristics of the procedure. ${ }^{7}$ The indirect/ non-invasive method is performed to evaluate the presence of maldigestion or the decrease in pancreatic performance in digestion process through stool and urine examination. This method is usually cheaper and easy to perform. There are several options that can be used, including faecal chymotrypsin test, faecal elastase-1, pancreolauryl/NBT-PABA test in the urine and serum, ${ }^{13} \mathrm{C}$ - triglyceride breath test, and stool fat analysis in 3 days. Among those tests, the more superior test was the faecal-elastase 1 level which has high sensitivity and specificity values, almost similar to direct method. ${ }^{7-9,12}$ A study on pancreatic exocrine insufficiency in pancreatic cancer through faecal elastase-1 level has been performed in advanced stage/unresectable pancreatic cancer and found that most pancreatic cancer patients had decreased faecal elastase- 1 level. ${ }^{6}$ Conversely, in patients with early stage/resectable pancreatic cancer, this has not been elucidated, probably because the difficulty in diagnosing pancreatic cancer in its early stage. Insufficiency of pancreatic exocrine function was closely related to other sequences of complications, ranging from the mildest symptoms in the forms of isolated pain, stomach cramp, or steatorrhea, to other manifestations that may potentially disrupts the patients' quality of life, such as severe malnutrition, bone deformity, and cardiovascular events as a result of absorption disorders of fat soluble vitamins, including vitamins A, D, E, K. ${ }^{5,10,11}$ This will surely poses big impact in patients' life because it may decrease their nutritional status and quality of life. Therefore, researcher meant to find the proportion of pancreatic exocrine insufficiency in patients with pancreatic cancer, which can be detected with faecal elastase-1 level. Additionally, the study on this topic has not been performed in our country. The study regarding PEI has been initiated in developed countries, but still focusing on PEI due to cystic fibrosis and chronic pancreatitis, while the study on PEI due to pancreatic cancer was still limited. Moreover, there was no study on the mean difference of faecal elastase-1 levels based on the pancreatic cancer stage.

This study was performed with general aim to identify the degree of exocrine pancreas insufficiency in pancreatic cancer and specific aim to determine the proportion and degree of exocrine pancreas insufficiency in pancreatic cancer (none, mildmoderate, severe), the proportion of steatorrhea in pancreatic cancer, the difference of faecal elastase-1 concentration between resectable and unresectable pancreatic cancer and the mean difference of faecal elastase- 1 concentration based on pancreatic cancer stage.

\section{METHOD}

This study was performed using a cross sectional study design to determine the proportion of exocrine pancreas insufficiency caused by pancreatic cancer, proportion of clinical symptoms of exocrine pancreas insufficiency, and difference of faecal elastase-1 concentration based on pancreatic cancer stage. The study was conducted in November 2014 until Mei 2015. This study was performed in Internal Medicine Polyclinic and Internal Medicine Inpatient Ward in Cipto Mangunkusumo Hospital, several partner hospitals of Cipto Mangunkusumo Hospital, and Wahidin Sudirohusodo Hospital Makasar. Examination of faecal elastase-1 concentration was performed in Prodia Laboratorium, Jakarta.

The target population in this study was patients diagnosed with pancreatic cancer. Accessible population in this study was patients diagnosed with pancreatic cancer who sought treatment in Gastroenterology Polyclinic or being hospitalized in Internal Medicine Inpatient Ward 
in Cipto Mangunkusumo Hospital. Study participants were patients who fulfilled the inclusion criteria and gave consent to participate in this study. Sampling was performed using consecutive sampling method.

In order to determine the proportion of PEI in pancreatic cancer, the required sample size in this study was calculated using the following formula, $\mathrm{n}=$ $\mathrm{Z} \alpha^{2 *} \mathrm{PQ} / \mathrm{d}^{2}$ [n: minimum sample size; type I error $(\alpha)$ $=5 \%$, thus $\mathrm{Z} \alpha=1,96 ; \mathrm{P}$ : prevalence of disease in the literature $=68-92 \%(87 \%) ; \mathrm{Q}=1-\mathrm{P}$; d: acceptable deviation (d) was $\pm 10 \%$ or 0,1$]$.

Based on this calculation, the minimum sample size required to determine the proportion in this study was 43 participants. In order to determine faecal elastase 1 concentration between resectable and unresectable pancreatic cancer, the required sample size in this study was calculated using the formula as follows: $\mathrm{n} 1$ $\left.=\mathrm{n} 2=2\left[(\mathrm{z} \alpha+\mathrm{z} \beta)^{*} \mathrm{~S}\right] /(\mathrm{X} 1-\mathrm{X} 2)\right]^{2}(\mathrm{n}=$ minimum sample size; $Z \alpha=$ type $I$ error $(\alpha)=5 \%$, thus $Z \alpha=$ 1,$96 ; Z \beta=$ type II error $(\beta)=10 \%$, thus $Z \beta=1,645 ; S$ $=$ combined standard deviation $=122 ; \mathrm{X} 1-\mathrm{X} 2=$ mean difference $=147$ )

The required sample to find this mean difference was 18 participants. In order to find the mean difference of faecal elastase 1 concentration based on pancreatic cancer stage, the sample size required for this study was calculated using the formula: effect size $=f=d^{*} \sqrt{ } 1 / 2 k$ ( $d=$ the biggest mean between groups/overall standard deviation; $\alpha=5 \%$; power effect size $=80 \%=0.6 ; \mathrm{k}=6$ ). ${ }^{33}$

The number of samples required to determine the mean difference of faecal elastase 1 based on pancreatic cancer stage was 42 participants. Hence, the minimum sample size required for this study was 43 participants, as the largest sample size to find all the four aims in this study.

The inclusion criteria were patients diagnosed with pancreatic cancer and be willing to participate in this study and signed the informed consent. The exclusion criteria included patients with pancreatic cancer and diabetes mellitus, patients with pancreatic cancer with Celiac disease, and patients with pancreatic cancer with Crohn's disease. Patients who sought treatment in Gastroenterology Division polyclinic or hospitalized in the Internal Medicine Inpatient Ward Cipto Mangunkusumo Hospital, several partner hospital of Cipto Mangunkusumo Hospital, and Wahidin Sudirohusodo Makasar Hospital with the diagnosis of pancreatic cancer, based on anamnesis, physical examination, ultrasound, CT Scan, EUS, and laboratory examination for $\mathrm{Ca}$ 19-9, will be given informed consent to participate in this study.
Patient was asked to collect faeces in a bottle or non sterile container. Faeces was then brought and tested in Prodia Jakarta Laboratory for the faecal elastase 1 test. Elastase 1 examination was performed using ELISA method using Leader ELISA equipment based on the available standard and immunoassay in Prodia Jakarta clinical laboratory. Collected data was analysed using computer with SPSS software version 21.0. Results of PEI proportion data in pancreatic cancer were stated in percentage and confidence interval. Degree of pancreas exocrine insufficiency or the presence of clinical symptoms was evaluated for its distribution and stated in percentage form, presented descriptively. The mean difference of faecal elastase- 1 concentration between resectable and unresectable pancreatic cancer was analysed using student T-test of Mann Whitney if the distribution was not normal. The mean difference of faecal elastase 1 concentration and pancreatic cancer stage was analysed using one-way ANOVA if it was normally distributed or Kruskal Wallis if it was not normally distributed. This study has received approval from Faculty of Medicine Universitas Indonesia Health Research Ethical Committee with ethical clearance No. 772/UN2.F1/ETIK/2014. The hypothesis of this study was that the faecal elastase 1 concentration in resectable pancreatic cancer was higher compared to that of unresectable pancreatic cancer.

\section{RESULTS}

During 6 months period from November 2014 to Mei 2015, based on abdominal ultrasound, abdominal CT Scan, endoscopic ultrasonography (EUS), MRCP, and ERCP, we recruited 48 subjects with pancreatic cancer diagnosis to participate in this study. These patients came from several hospitals in Jakarta, involving 33 participants from Cipto Mangunkusumo Hospital, 1 participant from Abdiwaluyo Hospital, 3 participants from Pelni Petamburan Hospital, 1 participant from Siloam Kebon Jeruk Hospital, and 10 participants from Wahidin Sudirohusodo Makasar Hospital.

From all patients diagnosed with pancreatic cancer, $24(50 \%)$ participants were male $24(50 \%)$ participants were female with the mean age of 56,05 years. The mean haemoglobin level in these participants was $10,24 \mathrm{gr} / \mathrm{dL}$, and the mean blood glucose was 123,70 $\mathrm{mg} / \mathrm{dL}$. The mean BMI of these participants was 18,2 $\mathrm{kg} / \mathrm{m}^{2}$, median bilirubin level was $14,55 \mathrm{gr} / \mathrm{dL}$, median Ca19-9 was $684,25 \mathrm{U} / \mathrm{mL}$, and median faecal elastase 1 level was $36,0 \mu \mathrm{g} / \mathrm{g}$. 
Table 1. Characteristics of study participants

\begin{tabular}{|c|c|c|c|}
\hline Variables & n (\%) & Mean (SD) & Median \\
\hline \multicolumn{4}{|l|}{ Sex } \\
\hline Male & $24(50,0)$ & & \\
\hline Female & $24(50,0)$ & & \\
\hline Age, (years) & & 56,04 (SD 11,33) & \\
\hline Weight (kg) & & 48,19 (SD 7,77) & \\
\hline Height $(\mathrm{cm})$ & & 157,94 (SD 6,47) & \\
\hline Body mass index $(\mathrm{BMI})\left(\mathrm{kg} / \mathrm{m}^{2}\right)$ & & & $18,2(14,32-26,67)$ \\
\hline Haemoglobin (g/dL) & & $10,24(S D 1,74)$ & \\
\hline Bilirubin (mg/dL) & & & $14,55(0,13-51,65)$ \\
\hline Blood glucose (mg/dL) & & $123,70(\mathrm{SD} 28,80)$ & \\
\hline Ca 19-9 (U/mL) & & $684,25(1,50-107776,01)$ & \\
\hline Faecal elastase $1(\mu \mathrm{g} / \mathrm{g})$ & & & $36,0(15-500)$ \\
\hline \multicolumn{4}{|l|}{ Pancreatic cancer stage } \\
\hline $\mathrm{IA}$ & 0 & & \\
\hline IB & $11(22,9)$ & & \\
\hline$\| \mathrm{A}$ & $8(16,7)$ & & \\
\hline II B & 0 & & \\
\hline III & $14(29,2)$ & & \\
\hline IV & $15(31,2)$ & & \\
\hline
\end{tabular}

Based on the staging system from The American Joint Committee on Cancer (AJCC), we found no subjects with stage IA and II B. There were $11(22,9 \%)$ participants with stage IB, $8(16,7 \%)$ participants with stage II A, $14(29,2 \%)$ participants with stage III, and $15(31,3 \%)$ participants with stage IV (Table 1).

Based on the results of faecal elastase 1 examination, in this study we found that the proportion of patients with pancreatic cancer experiencing PEI was $75 \%$ (95\% CI: $0,63-0,87)$ and $25 \%$ normal or no exocrine pancreas insufficiency was found. Among participants who suffered from exocrine pancreas insufficiency $66,7 \%$ had severe exocrine insufficiency, and $8,3 \%$ had mild-moderate exocrine insufficiency (Table 2 and Table 3).

Table 2. Proportion of PEl in cancer

\begin{tabular}{clc}
\hline PEI in pancreatic cancer & $\mathbf{n ~ ( \% )}$ & $\mathbf{9 5} \% \mathbf{C l}$ \\
\hline Yes & $36(75)$ & $0,63-0,87$ \\
No & $12(25)$ & \\
\hline
\end{tabular}

Table 3. Proportion and degree of insufficiency of pancreas exocrine in pancreatic cancer

\begin{tabular}{ll}
\hline Degree of exocrine insufficiency & $\mathbf{n}(\%)$ \\
\hline Severe $(<100)$ & $32(66,7)$ \\
Mild-moderate $(100-200)$ & $4(8,3)$ \\
None $(>200)$ & $12(25,0)$ \\
\hline
\end{tabular}

From the history taking, we found that the proportion of pancreatic cancer which manifested as steatorrhea was $68,8 \%(95 \%$ CI: $0,557-0,819)$ and the rest $31,2 \%$ did not show symptoms of steatorrhea (Table 4).
Table 4. Proportion of steatorrhea in pancreatic cancer

\begin{tabular}{ccc}
\hline Steatorrhea in pancreatic cancer & $\mathbf{n ~ ( \% )}$ & $\mathbf{9 5 \%} \mathbf{~ C l}$ \\
\hline Yes & $33(68,8)$ & $0,557-0,819$ \\
No & $15(31,2)$ & \\
\hline
\end{tabular}

Saphiro Wilk normality test showed that the faecal elastase I concentration data was not normally distributed $(p>0.05)$, thus we proceed with Mann-Whitney test. Difference of faecal elastase I concentration between resectable and unresectable pancreatic cancer can be seen in table 5:

Table 5. Difference in faecal elastase 1 concentration between resectable and unresectable pancreatic cancer

\begin{tabular}{lccc}
\hline \multirow{2}{*}{ Variable } & \multicolumn{2}{c}{ Staging category } & \multirow{2}{*}{$\mathbf{p}$} \\
\cline { 2 - 3 } & resectable & Unresectable & \\
\hline $\begin{array}{l}\text { Faecal Elastase 1 } \\
\text { concentration }\end{array}$ & $38,0(15-500)$ & $35,0(15-500)$ & 0,738 \\
\hline *Mann-Whitney test & & & \\
\hline
\end{tabular}

From table 4, we found that the mean value of faecal elastase 1 concentration in resectable group was $38,0(15-500) \mu \mathrm{g} / \mathrm{g}$ and in the unresectable group was 35,0 (15-500) $\mu \mathrm{g} / \mathrm{g}$. After Mann Whitney test was performed, we found that there was no significant difference in the faecal elastase 1 concentration $(\mathrm{p}=$ 0,738 ) between the resectable and unresctable group.

Saphiro Wilk normality test showed that the faecal elastase 1 concentration was not normally distributed, hence we proceed with Kruskal Wallis test to evaluate the mean difference of faecal elastase 1 concentration based on the pancreatic cancer staging.

The mean difference of faecal elastase 1 concentration based on the pancreatic cancer stage can be seen in Table 6: 
Table 6. Mean difference of faecal elastase 1 concentration based on the pancreatic cancer staging

\begin{tabular}{lccccc}
\hline \multirow{2}{*}{ Variable } & \multicolumn{4}{c}{ Stage } & \multirow{2}{*}{ P } \\
\cline { 2 - 5 } & IB & IIA & III & IV & \\
\hline $\begin{array}{l}\text { Faecal elastase 1 concentration } \\
(\mu \mathrm{g} / \mathrm{g})\end{array}$ & 36 & 62 & 15 & 36 & \multirow{2}{*}{$(15-100)$} \\
\hline *Kruskal Wallis test & & $(15-500)$ & $(15-500)$ & $(15-500)$ & 0,767 \\
\hline
\end{tabular}

Based on the Kruskal Wallis test, we found that there was no significant difference in the median of faecal elastase 1 concentration based on pancreatic cancer stage $(p=0,767)$. In this analysis, we found that the median value (range) in stage IB was $36(15-100)$ $\mu \mathrm{g} / \mathrm{g}$, stage IIA $62(15-500) \mu \mathrm{g} / \mathrm{g}$, stage III 15 (15$500) \mu \mathrm{g} / \mathrm{g}$, and stage IV $36(15-500) \mu \mathrm{g} / \mathrm{g}$. Therefore, it could be concluded that there was no difference in the faecal elastase 1 concentration based on pancreatic cancer stage.

\section{DISCUSSION}

In pancreatic cancer, complications due to pancreatic duct obstruction may occur, particularly if the tumour location was in the pancreatic head, which may inhibit the enzyme and bicarbonate transfer to the duodenum, which may be required in digestion process. This physiological disturbance may cause inadequate enzyme activity to maintain normal digestion process, which is known as pancreatic exocrine function insufficiency or pancreatic exocrine insufficiency (PEI). ${ }^{7-9}$

Diagnosis of PEI can be evaluated directly and indirectly. Direct method is the gold standard with highest sensitivity and specificity values, but practically, this method is difficult to apply due to the difficult processing, limited cost and human resources, and the invasive characteristics. One of the non-invasive methods which has high sensitivity and specificity to diagnose PEI was the examination of faecal elastase 1 level. ${ }^{7,22,23}$ Using the faecal elastase 1 level concentration, we can determine the PEI degree. Faecal elastase 1 level was considered normal if the value is more than $200 \mu \mathrm{g} / \mathrm{g}$ faeces. Mild to moderate pancreatic insufficiency was shown with the value of $100-200 \mu \mathrm{g} / \mathrm{g}$, while value below $100 \mu \mathrm{g} / \mathrm{g}$ revealed severe insufficiency. ${ }^{20}$

The clinical implication of this study is important, because the faecal elastase 1 level may be a marker of pancreatic exocrine insufficiency which may be a guide to determine substituting enzyme therapy and diet modification on patients with pancreatic cancer who suffered from PEI.
In this study, there were 48 participants consisting of $24(50 \%)$ male and $24(50 \%)$ female diagnosed with pancreatic cancer with the mean age of 56.05 years. From all imaging procedure used to diagnose pancreatic cancer, three-phase abdominal CT Scan with contrast was the method with high sensitivity and specificity. The high diagnostic accuracy in that imaging decrease the need of endoscopic USG which has higher sensitity and specificity (92\% and $96 \%$ ) or even CT Scan - guided biopsy (sensitivity $80-90 \%$, specificity $98-100 \%$ ) thus this procedure is only performed if there is doubt in establishing the diagnosis. From those examinations, we can determine the pancreatic cancer stage. ${ }^{16}$

In this study, based on the staging system from The American Joint Committee on Cancer (AJCC), there was no participant with stage IA and IIB. There were $11(22,9 \%)$ participants with stage I B, 8 $(16,7 \%)$ stage II A, 14 (29,2\%) stage III, and 15 (31,2\%) stage IV. The results of this study showed that most patients with pancreatic cancer was only diagnosed in advanced stage; therefore, it was not possible to be resected. This was in accordance with the report of Saif MW..$^{32}$ in year 2012, who obtained that only $20 \%$ of pancreatic cancer patients which was resectable during diagnosis. Similar condition was also reported by American Cancer Society who stated that pancreatic cancer was rarely diagnosed in the early stage. ${ }^{1}$ It seemed that routine screening for the diagnosis of pancreatic cancer in patients with high risk, particularly those with family history of pancreatic cancer need to be performed to diagnose pancreatic cancer in the early stage.

Based on the result of faecal elastase 1 level, in this study, it was found that the proportion of pancreatic cancer patients suffering from PEI was 75\% (95\% CI: $0,63-0,87)$ NS $25 \%$ normal or did not suffered from pancreatic exocrine insufficiency. Among subjects who experienced pancreatic exocrine insufficiency, $66.7 \%$ was included in severe exocrine insufficiency, and $8.3 \%$ suffered from mild-moderate exocrine insufficiency. The results of this study was similar to the results reported by Bhattaharje D et al which was 68-92\% patients with pancreatic cancer suffered from PEI. Study by Caletti A et al. ${ }^{12,35}$ who performed study 
in 86 patients with advanced stage pancreatic cancer $53 \%$ suffered from PEI. This was in accordance to the study by Crippa S, et al. ${ }^{36}$ who performed study in 194 patients with advance stage pancreatic cancer, as much as $50 \%$ suffered from PEI. In this study, particularly, it was found that $60.5 \%$ patients with advance stage pancreatic cancer suffered from PEI.

Based on the results of this study, the faecal elastase 1 level showed high clinical importance in diagnosing PEI in pancreatic cancer; hence, it can be used as a guide to determine the administration of substituting enzyme therapy and diet modification in patients with pancreatic cancer who suffered from PEI. The clinical consequence which manifested as symptoms of PEI was fat maldigestion and malabsorption, leading to steatorrhea, which was faeces sticking to the closet or float and difficult to flush, foamy, or foul odour. Steatorrhea was diagnosed as faecal fat level more than $7 \mathrm{gr} / 100$ gram of fat consumption. In this study, the diagnosis of steatorrhea was based on history taking and not stool fat examination. ${ }^{7}$ We acknowledged that the study based on history taking has a high bias.

In this study, the proportion of steatorrhea in patients with pancreatic cancer was quite high, which was $68.8 \%$ (95\% CI: $0.557-0.819)$. In a similar study by Dameria V, et al. ${ }^{32} 80-90 \%$ pancreatic cancer patients suffered from steatorrhea. The opposite was found in the study of Parteli S et al. ${ }^{6}$ who reported that from 194 patients included in advanced stage, only $20(10.3 \%)$ suffered from steatorrhea.

The presence of variation in steatorrhea proportion in patients with pancreatic cancer was probably caused by the variation of fatty food intake in different countries, method of examination and the diagnostic tool being used. The high proportion of steatorrhea showed that the presence of fat maldigestion and malabsorption. Therefore, patients with pancreatic cancer with steatorrhea symptoms were very likely to suffered from PEI, thus substituting enzyme therapy need to be administered and diet modification was needed, so that patients did not suffered from malnutrition. Faecal elastase 1 level examination was one of the non-invasive methods to examine pancreatic exocrine function. Faecal elastase 1 level is a good diagnostic marker to evaluate PEI because did not experience degradation in the digestive tract passage. ${ }^{21}$

Based on the results of faecal elastase 1 level, there were 13 participants in the resectable group who suffered from PEI and 23 participants in the unresectable group. In the resectable group, the median value of faecal elastase 1 level was 38.0 (15-500) $\mu \mathrm{g} / \mathrm{g}$, while in the unresectable category was 35,0 (15$500) \mu \mathrm{g} / \mathrm{g}$. Thus far, there is no study comparing the difference of elastase 1 level between resectable and unresectable cancer. The absence of difference in faecal elastase 1 level between resectable and unresectable patients showed that the severity of pancreatic exocrine insufficiency evaluated using faecal elastase 1 level examination was not based on the pancreatic cancer stage, but the extent of tumour causing pancreatic duct obstruction. According to Gavastro GM, dkk. ${ }^{37}$ patients with pancreatic head cancer showed lower faecal elastase 1 level $(189.4 \pm 180.7)$ compared to pancreatic cancer of the body and tail $(421.2 \pm 229.1)$. This was in accordance to the study of Kellar J et al. ${ }^{13}$ which reported that the manifestation of pancreatic exocrine insufficiency only occurred if there was more than $60 \%$ obstruction in pancreatic duct.

In this study, there was no significant difference in the median of faecal elastase 1 level based on pancreatic cancer stage $(p=0.767)$. In this study, the median value (range) of faecal elastase 1 in stage IB was $36(15-100) \mu \mathrm{g} / \mathrm{g}$, stage IIA $62(15-500) \mu \mathrm{g} / \mathrm{g}$, stage III $15(15-500) \mu \mathrm{g} / \mathrm{g}$, and stage IV $36(15-500) \mu \mathrm{g} / \mathrm{g}$. This showed that there was no significant difference in faecal elastase 1 level based on pancreatic cancer stage $(\mathrm{p}=0,767)$.

Parteli S et al had compared the faecal elastase 1 level in stage III and stage IV in 194 participants, but there was no significant difference in the faecal elastase 1 level between two groups, but none has performed study to evaluate the difference of faecal elastase 1 level in each stage of pancreatic cancer. ${ }^{6}$ We found that there was no significant mean difference based on pancreatic cancer stage showed that the severity of pancreas exocrine insufficiency evaluated through the faecal elastase 1 level was not based on the stage of pancreatic cancer, but the extent of tumour causing obstruction of the pancreatic duct.

This study involved patients with pancreatic cancer in several hospitals in Indonesia, including Cipto Mangunkusumo Hospital Jakarta, several partner hospitals of Cipto Mangunkusumo Hospital, and Wahidin Sudirohusodo Makasar Hospital. In addition to evaluating the mean difference of faecal elastase 1 level based on pancreatic cancer stage, this study also evaluated the mean difference of faecal elastase 1 level based on the clinical stage of pancreatic cancer, which were resectable and unresectable. This study included patients diagnosed with pancreatic cancer. It was planned to include all stage of pancreatic cancer, but in this study, we found very few cases of early stage 
pancreatic cancer as most patients came in advanced stage. Additionally, pancreatic duct obstruction as the cause of PEI and biliary duct obstruction as the cause of jaundice was not evaluated further. In this study, the diagnosis of steatorrhea was only based on anamnesis and was not confirmed with faecal fat examination as definitive diagnosis.

\section{CONCLUSION}

Based on the faecal elastase 1 results, we found higher PEI proportion in pancreatic cancer patients as much as $75 \%$ and $25 \%$ normal or no exocrine pancreas insufficiency. Among subjects who suffered from exocrine pancreas insufficiency, $66.7 \%$ suffered from severe exocrine insufficiency, and $8.3 \%$ suffered from mild-moderate exocrine insufficiency. In this study, we obtained high proportion of steatorrhea in patients with pancreatic cancer, which was $68.8 \%$. There was no difference in faecal elastase 1 level between participants with resectable and unresectable pancreatic cancer. There was no mean difference in the faecal elastase 1 level based on pancreatic cancer stage.

The proportion of PEI in patients with pancreatic cancer in this study was high, thus it was recommended that faecal elastase 1 be performed in pancreatic cancer patients. Further studies are required to further evaluate the effect of substituting enzyme administration and diet modification to quality of life in pancreatic cancer patients who also suffered from PEI.

\section{REFERENCES}

1. American Cancer Society. Pancreatic cancer. Atlanta; American Cancer Society: 2014.p.1-65.

2. Moghaddam AA, Huxley R, Barzi F. The effect of modifiable risk factors on pancreatic cancer mortality in populations of the Asia-pacific region. Cancer Epidemiol Biomarkers Prev 2006; 15:2435-40.

3. Oto BT, Fauzi A, Syam AF, Simadibrata M, Abdullah M, Makmun D, et al. Identification and stenting malignant obstructive jaundice: determining the success rate of ERCP. Indones J Gastroenterol Hepatol Dig Endosc 2012;13:19-22.

4. Kurniawan J, Hasan I, Gani R, Simadibrata M. Kesintasan tiga bulan pasien ikterus obstruktif dengan etiologi maligna dan faktor-faktor yang mempengaruhinya. Jakarta: Fakultas Kedokteran Universitas Indonesia;2014

5. Braddick JA, Flaherty MC. Management of pancreatic exocrine insufficiency. Oncology Nursing Forum 2013;40:116-9.

6. Partelli S, Frulloni L, Minniti C, Bassi C, Barugola G, Onofrio M, et al. Faecal elastase-1 is an independent predictor of survival in advanced pancreatic cancer. Dig Liver Dis 2012;44:945-51.

7. Toouli J, Biankin AV, Oliver MR, Pearce CB, Wilson JS, Wray NH. Management of pancreatic exocrine insufficiency:
Australasian Pancreatic Club recommendations. MJA 2010;193:461-7.

8. Suleiman SL, Kadiyala V, Conwell DL. Pancreatic exocrine insufficiency. Gastroenterology \& Endoscopy News. 2012: 1-7.

9. Munoz ED. Pancreatic exocrine insufficiency: Diagnosis and treatment. J Gastroenterol Hepatol 2011;2:12-6.

10. Holly EA, Chaliha I, Bracci PM, Gautam M. Signs and symptoms of pancreatic cancer: a population-based case-control study in the San Fransisco Bay Area. Clin Gastroenterol Hepatol 2004;2:510-7.

11. Hidalgo M. Pancreatic cancer. N Engl J Med 2010;362:160517.

12. Gelecek S, Bilgic I, Ozmen MM. Exocrine pancreatic insufficiency. Eur J Surg Sci 2012;3:75-9.

13. Keller J, Aghdassi AA, Lerch MM, Mayerle JV, Layer P. Tests of pancreatic exocrine function - Clinical significance in pancreatic and non-pancreatic disordes. Best Pract Res Clin Gastroenterol 2009;23:425-39.

14. Bhattacharjee D, Chowdhury S, Das S, Mukherjee S, Bhattacaryya BK. Treatment of pancreatic exocrine insufficiency with enteric coated pancreatin formulations: an overview. Int J Pharm Sci Nanotech 2013;6:2125-30.

15. Thomas PD, Forbes A, Green J, Howdle P, Long R, Playford $\mathrm{R}$, et al. Guidelines for the investigation of chronic diarrhoea, 2nd edition. Gut 2003;52:1-15.

16. Kanji ZS, Gallinger S. Diagnosis and management of pancreatic cancer. CNAJ 2013;4:1-8.

17. Owyang C, Williams JA. Pancreatic secretion. In: Yamada T, Alpers DH, Kalloo AN, Kaplowitz N, Owyang C, Powell DW, eds. Textbook of Gastroenterology. Volume 1. West Sussex: Wiley-Blackwell; 2009.p.903-12.

18. Dominici R, Franzini C. Faecal elastase-1 as a test for pancreatic function: a review. Clin Chem Lab Med 2002;40:325-32.

19. Daftary Am Acton J, Heubi J, Amin R. Faecal elastase-1: Utility in pancreatic function in cystic fibrosis. J Cyst Fibros 2006;5:71-6.

20. Lankisch PG. Secretion and absorption (methods and functions). Pract Res Clin Gastroenterol 2009;23:325-35.

21. Spillmann T, Witker A, Teigelkamp S, Eim C, Burkhardt E, Eigenbrodt $\mathrm{E}$, et al. An immunoassay for canine pancreatic elastase 1 as an indicator for exocrine pancreatic insufficiency in dogs. J Vet Diagn Invest 2001;13;468-74.

22. Symersky T, Zon A, Biemond I, Masclee AA. Faecal elastase-I: helpful in analysing steatorrhoea. Neth J Med 2004;62:286-9.

23. Walkowiak J, Herzig KH, Strzykala K, Pryzslawski J, Krawczynski M. Faecal elastase-1 is superior to faecal chymotripsin in the assessment of pancreatic involvement in cystic fibrosis. Pediatrics 2002;110:1-4.

24. Loser C, Mollgaard A, Folsch UR. Faecal elastase 1: A novel, highly sensitive, and specific tubeless pancreatic function test. Gut 1996;39:580-6.

25. Walkowiak J, Arvanitakis SN, Cade A, Kashirskaya N, Piotrowski R, Strzykala K, et al. Faecal elastase-1 cut-off levels in the assessment of exocrine pancreatic function in cystic fibrosis. J Cyst Fibros 2002;1:260-4.

26. Stein J, Jung M, Sziegoleit A, Zeuzem S, Caspary WF, Lembcke B. Immunoreactive elastase 1: clinical evaluation of a new noninvasive test of pancreatic function. Clinical Chemistry 1996;42:222-6.

27. Sonwalkar SA, Holbrook IB, Phillips I, Kelly SM. A prospective, comparative study of the para-aminobenzoic 
acid test and faecal elastase 1 in the assessment of exocrine pancreatic function. Aliment Phamacol Ther 2003;17:467-71.

28. Brydon WG, Kingstone K, Ghosh S. Limitations of faecal elastase-1 and chymotrypsin as tests exocrine pancreatic disease in adults. Journals of Clinical Biochemistry 2004;41:78-81.

29. Lankisch PG, Schmidt I, Konig H, Lehnick D, Knollmann $\mathrm{R}$, Lohr M, et al. Faecal elasase 1: not helpful in diagnosing chronic pancreatitis associated with mild to moderate exocrine pancreatic insufficiency. Gut 1998;42:551-4.

30. Nousia S, Arvanitakis. Faecal elastase-1 concentration: an indirect test of exocrine pancreatic function and a marker of an enteropathy regardless of cause. J Pediatr Gastroenterol Nutr 2003;36:314-5.

31. Naruse S, Ishiguro H, Shigebu BH, Yoshikawa T, Yamamoto T, Yamamoto A, et al. Faecal pancreatic elastase: a reproducible marker for severe exocrine pancreatic insufficiency. J Gastroenterol 2006;41:901-8.

32. Damerla V, Gotlieb V, Larson H, Saif W. Pancreatic enzyme supplementation in pancreatic cancer. J Support Oncol 2008;6:393-6.

33. Ariawan I. Besar dan metode sampel pada penelitian kesehatan. Depok : Fakultas Kesehatan Masyarakat Universitas Indonesia 1998.p.57-8.

34. Saif MW. Revising you staging for pancreatic cancer in 2012. JOP 2012;13: 128-30.

35. Callatti A, Festa L, Padovani M. Incidence at diagnosis of exo- endocrine insufficiency in advanced pancreatic cancer patients. JOP 2007;8:651.

36. Crippa S, Partelli S, Frulloni L. Pancreatic exocrine insufficieny in advanced pancreatic cancer: faecal elastase1 (fe-1) value is a strong indepent predictor of poor survival. JOP 2011;12:507-8.

37. Cavestro GM, Nouvenne A, Merli R. Role of faecal elastase 1 in pancreatic cancer. JOP 2004;5:432-3. 